
ПАТОГЕНЕЗУ АТЕРОСКЛЕРОЗУ У ХВОРИХ НА ЗАПАЛЬНІ ЗАХВОРЮВАННЯ СУГЛОБІВ

\title{
O.о. Гарміш
}

ДУ «Національний науковий центр «Інститут кардіології ім. акад. М.Д. Стражеска» НАМН України, м. Київ

Ключові слова:

атеросклероз, ішемічна хвороба серия, ліпіди, ліпопротеїни, метаболізм, апоА-I, anoB.

Буковинський медичний вісник. T.24, № 4 (96). C. $12-18$.

DOI: $10.24061 / 2413-0737$. XXIV.4.96.2020.97

E-mail: garmish.elena@ gmail.com
Мета дослідження - вивчити особливості порушень обміну ліпідів та ліпопротеїнів (ЛП) крові у хворих на системні ревматичні захворювання. Матеріал і методи. У всіх пацієнтів визначали рівень С-реактивного протеїну (СРП), вміст малонового альдегіду (МА) у ичиркулюючих моноицтах. Про наявність і вираженість проатерогенного статусу судили за вмістом у крові модифікованих ліпопротеїнів низької щільності (ЛПНЩ) і ліпопротеїнів дуже низької щільності (ЛПДНЩ), який визначали методом біотестування із застосуванням перитонеальних макрофагів мишей. Визначали вміст у крові ииркулюючих імунних комплексів (ЦІК), імуногенність модифікованих ЛП за вмістом у ЦІК холестерину (ХС) та триглічеридів (ТГ). Детально оцінювали спектр ліпідів та ліпопротеїнів у крові з додатковим визначенням рівня білків апоВ та апоА-1 у плазмі крові. Результати. Отримані дані свідчать про наявність у досліджених хворих вираженного системного запалення у поєднанні з виразним проатерогенним метаболічним статусом у вигляді модифікаиії ліпопротеїнів та появою у них аутоантигенних властивостей. Ці зміни виникали незважаючи на відсутність змін традиційних факторів атерогенезу.

Висновки. При визначенні проатерогенних порушень обміну ліпідів та ліпопротеїнів крові у пацієнтів із системними ревматичними захворюваннями необхідно орієнтуватися не на традииійні фактори ризику, які можуть залишатися в межах нормальних значень, а на вміст білків апоА-1, апоВ, їх співвідношення, на визначення модифікованих ліпопротеїнів крові та вираженість аутоімунної реакиії на них.

\section{ХАРАКТЕР НАРУШЕНИЙ ОБМЕНА ЛИПОПРОТЕИНОВ КРОВИ КАК ОСНОВЫ ПАТОГЕНЕЗА АТЕРОСКЛЕРОЗА У БОЛЬНЫХ С ВОСПАЛИТЕЛЬНЫМИ ЗАБОЛЕВАНИЯМИ СУСТАВОВ}

\section{E.А. Гармиш}

Ключевые слова:

атеросклероз, ишемическая болезнь сердиа, липиды, липопротеины, метаболизм, апоА-I, anoB.

Буковинский медииинский вестник. T.24, № 4 (96). C.12-18.
Цель исследования - определение особенностей нарушения обмена липидов и липопротеинов (ЛП) крови у 112 больных с системными ревматическими заболеваниями.

Материал и методы. У всех пациентов определяли уровень С-реактивного протеина (СРП), содержание малонового альдегида (МА) в ичиркулирующих моноцитах. О наличии и выраженности проатерогенного статуса судили по содержанию в крови модифицированных липопротеинов низкой плотности (ЛПНП) и липопротеинов очень низкой плотности (ЛПОНП), которое определяли методом биотестирования с использованием перитонеальных мылииных макрофагов. Определяли содержание в крови циркулирующих иммунных комплексов (ЦИК), иммуногенность модифицированных ЛП по содержанию в ЦИК холестерина (ХС) и триглицеридов (ТГ). Детально оиенивали спектр липидов и липопротеинов в крови с дополнительным определением плазменного уровня белков апоB и апо $A-1$.

Результаты. Полученные данные свидетельствовали о наличии у ис- 
Original research

следованных больных выраженного системного воспаления в сочетании с отчетливым проатерогенным метаболическим статусом в виде модификации липопротеинов и появлением у них аутоантигенных свойств. Эти изменения возникали, несмотря на отсутствие достоверных изменений традиционных факторов атерогенеза.

Выводы. При определении проатерогенных нарушений обмена липидов и липопротеинов крови у пациентов с системными ревматическими заболеваниями необходимо ориентироваться не на традиционные факторы риска, которые могут оставаться в пределах нормальных значений, а на содержание белков апо A-1, апоB, их соотношение, на определение модифицированных липопротеинов крови и выраженности аутоиммунной реакции на них.

\section{THE NATURE OF METABOLIC DISORDERS OF BLOOD LIPOPROTEINS AS THE BASIS FOR THE PATHOGENESIS OF ATHEROSCLEROSIS IN PATIENTS WITH INFLAMMATORY JOINT DISEASES}

\section{O.O. Garmish}

Key words:

atherosclerosis, coronary heart disease, lipids, lipoproteins, metabolism, apoA-I, apoB.

Bukovinian Medical Herald. V.24, № 4 (96). P. 12-18.
Objective of this study was to determine the characteristics of the metabolic disorders of lipids and lipoproteins (LP) in the blood in 112 patients with systemic rheumatic diseases.

Material and methods. In all patients, the level of C-reactive protein (CRP), the content of malonic aldehyde (MA) in circulating monocytes, in blood plasma, and catalase activity were determined. The presence and severity of pro-atherogenic status were evaluated by the content of modified low-density lipoproteins $(L D L)$ and very-low-density lipoproteins $(V L D L)$ in the blood, which was determined by the bioassay method using peritoneal mouse macrophages. The immunogenicity of modified LP was determined by the content in the circulating immune complexes (CIC) of cholesterol (Chol) and triglycerides (TG). The spectrum of lipids and LP in the blood was evaluated in detail with an additional determination of the plasma level of proteins apoB and apoA-1 were determined.

Results. The obtained results show the existence in the examined patients of significant systemic inflammation in conjunction with the distinct proatherogenic metabolic state that was revealed by lipoprotein modification with the appearance in them of auto-antigenic properties. These changes appeared despite the absence of significant traditional atherogenic risk factors. The results of the paired correlative analysis showed the existence of strong dependence between indexes of systemic inflammation, proatherogenic and immunogenic lipoprotein modification.

Conclusions. When determining proatherogenic disorders of lipid and blood lipoproteins metabolism in patients with systemic rheumatic diseases, it is necessary to focus not on traditional risk factors, which may remain within normal values, but on the content of apoA-1, apoB proteins, their ratio, and the determination of modified lipoproteins blood and the severity of the autoimmune reaction to them.
Вступ. До теперішнього часу велика кількість дослідників розглядає патогенез атеросклерозу як наслідок дії гіперхолестеринемії (ГХЕ). Вона може бути пов'язана або з пригніченням захоплення холестерину (XC) клітинами внаслідок генетичного дефіциту рецепторів ліпопротеїнів (ЛП) низької щільності (ЛПНЩ), або з надлишковим його надходженням в організм за різного роду дієтичних порушень. Вважали, що в умовах ГХЕ посилюється проникнення ЛП через ендотеліальний бар'єр з накопиченням ХС у стінці артерій, що і є причиною їх атеросклеротичного ураження (інфільтраційна теорія М.М. Анічкова).

Уявлення про провідну роль ГХЕ в атерогенезі і зараз зберегли свої позиції, особливо серед клініцистів. Відповідно до цього, всі сучасні посібники по зниженню ризику розвитку ішемічної хвороби серця (IXC) приді- 
ляють головну увагу корекції вмісту в крові загального ХС та ХС ЛПНЩ за допомогою відповідних дієтичних втручань, а за відсутності їх ефекту рекомендують застосування агресивної ліпідкоригувальної терапії $[1,2]$.

Проте ці уявлення перебувають в очевидному протиріччі $з$ даними про те, що в багатьох осіб з вираженою IXC і навіть наявністю інфаркту міокарда (IM) рівень загального ХC та ХС ЛПНЩ залишається в межах норми. Згідно з нещодавно проведеним метааналізом результатів дослідження, більше як 27 тисяч здорових жінок Америки, 77 \% наступних коронарних явищ виникало у випадках, коли вихідний рівень ХС ЛПНЩ не перевищував 4,14 ммоль/л (160 мг/дл), а 45 \% наслідків відзначались навіть при значеннях цього показника менше 3,36 ммоль/л або 130 мг/дл [3]. Більше того, наявність ГХЕ зумовлювало розвиток атеросклерозу та IXC не більше, як у 50 \% усіх випадків [4].

Ці протиріччя були вирішені в ряді фундаментальних робіт, які дозволили значно поглибити розуміння природи процесів, що лежать в основі атерогенезу. Відповідно до результатів генетичних, гістопатологічних та епідеміологічних досліджень, порушення обміну ліпідів та ЛП плазми і тепер розглядають як провідний фактор патогенезу атеросклерозу та IXC, проте трактовка характеру цих порушень суттєво змінилась.

Крім того, до останнього часу основна увага приділялась тільки кількісній стороні порушень, тобто збільшенню вмісту в крові ХС або ТГ і, відповідно, окремих класів ЛП, які є їх переносниками. Проте згідно з результатами сучасних досліджень, вираженість виникаючих порушень $€$ тільки відображенням інтенсивності процесу, тоді як в його основі лежать, перш за все, зміни в структурі та функціональних властивостях окремих класів ЛП, у результаті чого повністю спотворюється характер їх метаболізму. У цих умовах виникають так звані „модифіковані ЛП”, які мають цитотоксичну дію і властивості чужорідних тіл, тобто здатність пошкоджувати судинний ендотелій, активувати клітини макрофагальної системи і захоплюватись ними, викликати розвиток запальної реакції $[5,6]$.

У низці досліджень встановлено, що підвищений ризик кардіоваскулярної патології при ревматоїдному артриті (РА) пов'язаний також із наявністю дисліпідемії, проте вона має особливий характер, типовий для гострої фази запальної відповіді. При цьому вміст загального ХC та ХС ЛПНЩ може як зростати, так і зменшуватись, вміст ХС ЛПВЩ закономірно зменшується, а проведення ефективної антиревматичної терапії суттєво зменшує вираженість цих порушень [7].

Таким чином, у хворих на РА та інші системні ревматичні захворювання значимість класичних факторів кардіоваскулярного ризику мають суттєві відмінності від традиційних, насамперед у характері порушень обміну ліпідів, спектра ліпопротеїнів крові, у вираженості системного запалення та в його якісних особливостях. Однак ці питання залишаються на теперішній час недостатньо вивченими і дискусійними.

Мета дослідження. Вивчити особливості порушень обміну ліпідів та ЛП крові у хворих на системні ревматичні захворювання.

Матеріал і методи. Дослідження проведене з включенням 112 осіб із системними ревматичними захворюваннями (25 - 3 анкілозивним спондилітом, 87 - 3 РА). Середній вік хворих склав $(39,7 \pm 8,1)$ років, серед досліджених було 73 жінки і 39 чоловіків. Всі хворі отримували традиційне антиревматичне лікування 3 включенням більш ніж у 70 \% випадків препаратів біологічної терапії.

У всіх досліджених визначалась активність системного запалення за рівнем у крові СРП та вмістом малонового альдегіду (МА) у циркулюючих моноцитах, як показник їх активації. Про наявність і вираженість проатерогенного статусу судили за вмістом у крові модифікованих ЛПНЩ і ЛПДНЩ, який визначали методом біотестування із застосуванням перитонеальних макрофагів мишей. Участь імунного компонента в розвитку запалення оцінювали за вмістом у плазмі крові циркулюючих імунних комплексів (ЦІК) різних класів (дрібних, середніх і великих), імуногенність модифікованих ЛП визначали за вмістом холестерину (ХC) та тригліцеридів (ТГ) у ЦІК. Детально оцінювали спектр ліпідів і ЛП крові з додатковим визначенням плазмового рівня апоВ і апоА-1 на полуавтоматичному біохімічному аналізаторі Cormay (Іспанія). Кров для дослідження забиралася 3 ліктьової вени вранці натще. Як референтні значення використовували дані, які отримано при дослідженні 30 практично здорових донорів.

Отримані дані оброблено статистично із застосуванням пакета аналізу програми Excel-2003 і використанням критерію Стьюдента. Критерієм вірогідності виявлених змін вважали $\mathrm{p}<0,05$.

\section{Результати дослідження та їх обговорення}

У всіх досліджених хворих встановлено наявність вираженого системного запалення. Це проявлялося підвищенням майже у 10 разів вмісту СРП у плазмі (від 1,25 \pm 0,1 до 11,09 $\pm 2,09$ мг/л, $\mathrm{p}<0,001)$ паралельно 3 активацією циркулюючих моноцитів, про що свідчило зростання вмісту в них МА (до 3,16 $\pm 0,10$ мкмоль/мг білка), що на 185 \% перевищувало контрольне значення $(1,11 \pm 0,09$ мкмоль/мг білка, $\mathrm{p}<0,001)$ (таблиця).

У досліджених хворих відзначена наявність проатерогенних порушень системного метаболізму, насамперед змін спектра ЛП крові. Однак характер цих змін суттєво відрізнявся від того, який характерний для традиційного розвитку атеросклерозу. Так, вміст загального ХС у крові становив $(5,12 \pm 0,15$ ммоль/л) і вірогідно не відрізнявся від нормального значення (5,01 $\pm 0,22$ ммоль/л), яке визначено у практично здорових досліджених. Вміст у плазмі крові ХС ЛПНЩ становив (3,42 \pm 0,14 ммоль/л) і статистично не відрізнявся від нормального значення. Концентрація ТГ у крові в досліджених пацієнтів дорівнювала (1,52 \pm 0,13 ммоль/л) і також достовірно не відрізнялася від нормального значення. Аналогічним чином вміст ХС ЛПДНЩ у крові не відрізнявся від нормального значення і становив $(0,69 \pm 0,05$ ммоль/л). Ці зміни поєднувалися зі зниженням рівня ХС ЛПВЩ 
Original research

(до 1,01 \pm 0,03 ммоль/л, p<0,05), що на $26 \%$ нижче нормального значення показника контрольної групи $(1,36 \pm 0,07$ ммоль/л).

Проте незважаючи на відсутність традиційних факторів атерогенезу, аналіз встановлених змін свідчив про наявність проатерогенних порушень обміну ЛП, оскільки коефіцієнт атерогенності, який визначався по відношенню плазмового змісту ТГ до ХС ЛПВЩ, був збільшений порівняно з нормою на 68 \% $(\mathrm{p}<0,001)$.

Крім того, якісні зміни ЛП, що відображають проатерогенний потенціал крові, перш за все вміст у ній апо-білків, у хворих на РА, носили достовірний і виражений характер. Концентрація у крові апоА-1, основного білка ЛПВЩ, який визначає їх функціональні властивості, становила (82,6 $\pm 2,73$ мг/дл) і була на 64 $\%$ нижча ( $<0,01)$, ніж у практично здорових досліджених контрольної групи (136,2 \pm 7,52 мг/дл). Навпаки, концентрація апоВ, головного апо-білка ЛПНЩ і ЛПДНЩ, становила $(105,18 \pm 3,40$ мг/дл) і перевищувала на $17 \%$ значення, яке встановлене в осіб контрольної групи $(92,02 \pm 2,52$ мг/дл, $\mathbf{p}<0,02)$. У результаті індекс атерогенності (IA), який визначався як відношення концентрації апоВ до апоА-1, склав $(1,39 \pm 0,11$ ум. од.) і на $90 \%$ перевищив нормальне значення $(0,71 \pm$ $0,19$ ум. од., $\mathrm{p}<0,001)$.

Підвищений проатерогенний потенціал крові і його залежність від модифікації ЛП, а не від кількісних змін їх концентрації в крові, підтверджений даними дослідження, яке проведене використанням культури мишачих макрофагів. Їх інкубація з дослідженою плазмою супроводжувалась зростанням внутрішньоклітинної концентрації ХC (до 262,45 \pm 4,80 мкг/мг білка), що було на $160 \%$ більшим, ніж після інкубації макрофагів 3 плазмою осіб контрольної групи $(101,1 \pm 11,8$ мкг/мг білка, $\mathrm{p}<0,001$ ) (рис.2). Ці дані відображали пропорційне посилене захоплення макрофагами ЛПНЩ у результаті їх модифікації та отримання ними аномальних властивостей. Вміст ТГ у макрофагах після інкубації з плазмою хворих на РА був у 7 разів більшим, ніж після їх інкубації з плазмою контрольних осіб (відповідно $38,7 \pm$ $1,2$ мкг/мг білка та 290,45 $\pm 10,01$ мкг/мг білка, $\mathrm{p}<0,001)$, що свідчило про виражену модифікацію ЛПДНЩ і про посилене їх захоплення макрофагами.

Зазначене запалення мало чітко виражений імунний характер, про що свідчило зростання як сумарної кількості ЦІК, так і концентрації їх фракцій - дрібних, середніх і великих ЦІК. Зміст фракції великих ЦІК було збільшено на $75 \%(\mathrm{p}<0,001)$, середніх - майже в 3 рази $(\mathrm{p}<0,001)$, дрібних, найбільш прозапальних, - майже у 2 рази $(\mathrm{p}<0,001)$. В імунній відповіді істотна роль належала аутоімунному компоненту і модифікованим ЛПНЩ і ЛПДНЩ, як аутоантигенам. Про це свідчило збільшення вмісту в ЦІК відповідно ХС у 6,1 раза порівняно з нормою (від 1,28 $\pm 0,08$ до 7,81 $\pm 0,11$ мг/л, $\mathrm{p}<0,001)$ та ТГ у 3,7 раза (від $1,03 \pm 0,08$ до $3,86 \pm 0,09$ мг/л, $\mathrm{p}<0,001)$.

Результати проведеного дослідження свідчать про те, що в осіб з РА навіть після проведеної специфічної фармакотерапії та значного зменшення вираженості системного запалення зберігається виражений проатерогенний фон у вигляді атерогенно-модифікованих ЛП. Ці зміни відбувалися незважаючи на відсутність у більшості пацієнтів клінічних проявів атеросклерозу і IXC та характерних для атерогенезу змін вмісту і спектра ЛП крові.

Результати цілого ряду експериментальних і клінічних досліджень свідчать про те, що нативні ЛП крові не мають атерогенних властивостей, незалежно від їх

Таблиця

Показники системного запалення, обміну ліпідів та ліпопротеїнів крові, їх імуногенності у досліджених хворих порівняно з контрольними показниками

\begin{tabular}{|c|c|c|c|}
\hline Показник & $\begin{array}{c}\text { Значення показника у } \\
\text { досліджених хворих }\end{array}$ & $\begin{array}{c}\text { Контрольне значення } \\
\text { показника }\end{array}$ & Р \\
\hline СРП, мг/л & $11,09+2,09$ & $1,25+0,10$ & $<0,001$ \\
\hline $\begin{array}{c}\text { МА в МЦ, мкмоль/мг } \\
\text { білка }\end{array}$ & $3,16+0,10$ & $1,11+0,09$ & $<0,001$ \\
\hline ХС, ммоль/л & $5,12+0,15$ & $5,01+0,22$ & $>0,05$ \\
\hline ТГ, ммоль/л & $1,52+0,13$ & $1,48+0,19$ & $>0,05$ \\
\hline ХС ЛПНЩ, ммоль/л & $3,42+0,12$ & $2,98+0,18$ & $>0,05$ \\
\hline ХС ЛПДНЩ, ммоль/л & $0,69+0,05$ & $0,67+0,04$ & $>0,05$ \\
\hline ХС ЛПВЩ, ммоль/л & $1,01+0,03$ & $1,36+0,07$ & $<0,05$ \\
\hline апоА-1, мг/дл & $82,60+2,73$ & $136,20+7,52$ & $<0,01$ \\
\hline апоВ, мг/дл & $105,18+3,40$ & $92,02+2,52$ & $<0,02$ \\
\hline ХС в ММ, мкг/мг білка & $262,45+4,80$ & $101,1+11,8$ & $<0,001$ \\
\hline ТГ в ММ, мкг/мг білка & $290,45+10,01$ & $38,7+1,2$ & $<0,001$ \\
\hline ХС в ЦІК, мг/л & $7,81+0,11$ & $1,28+0,08$ & $<0,001$ \\
\hline ТГ в ЦІК, мг/л & $3,86+0,09$ & $1,03+0,08$ & $<0,001$ \\
\hline
\end{tabular}


концентрації. Тільки при модифікації, головним чином перекисної природи, ЛП стають чужорідними для організму і захоплюються макрофагами через скевенджер-рецептори з утворенням пінистих клітин. Загальновизнано, що цей процес $є$ ключовим у патогенезі атеросклерозу і він не пов'язаний прямою залежністю між вмістом у плазмі загального ХС або ХС ЛПНЩ. Хоча, наявність ГХЕ відображає підвищений ризик розвитку атеросклерозу, він визначається не підвищенням рівня ХС, а здатністю ЛПНЩ ініціювати аутоокиснення 3 виникненням їх проатерогенного фенотипу.

Зміни ліпідного профілю у пацієнтів з РА не мають закономірного характеру, показано як підвищення, так і зниження або відсутність змін рівня загального ХC та ТГ [7]. Більше того, між рівнем ліпідів і тяжкістю перебігу захворювання, інтенсивністю запалення часто відзначається зворотна залежність. У багатьох клінічних дослідженнях збільшені функціональні та структурні індекси судинного ураження (ослаблення кровотік-залежної дилатації плечової артерії, потовщення КІМ сонних артерій, наявність атеросклеротичних бляшок) при РА закономірно відзначалися незалежно від традиційних кардіоваскулярних факторів ризику, що свідчило про їх переважний зв'язок з патогенетичними факторами РА. Якщо у пацієнтів з IXC без РА поширеність атеросклеротичних бляшок у сонній артерії становила 9,5\%, то в групі осіб з РА - 71 \%, навіть за відсутності виражених традиційних чинників атерогенезу.

При дослідженні осіб з РА, які не приймали глюкокортикоїдів або препаратів, що впливають на його активність, середній рівень ХС був у межах нормальних значень, хоча відношення ХС/ХС ЛПВЩ було вірогідно збільшеним. Практично у всіх осіб з РА була тенденція до зниження рівня ХС ЛПВЩ, наявність же закономірної зворотної залежності встановлена тільки при вірогідному збільшенні вмісту СРП, а також при позитивному аналізі на ревматоїдний фактор [8].

Тому, для більш точної оцінки ризику розвитку атеросклерозу та IXC у хворих на системні ревматичні захворювання потрібно визначати не тільки загальний вміст ХС та ТГ у крові, концентрацію в ній окремих фракцій ЛП, а і певні специфічні показники обміну ЛП крові, що вірогідно свідчитимуть про його проатерогенні зміни.

Одним із варіантів подібного аналізу є визначення вмісту в крові ХС не-ЛПВЩ, тобто сумарної концентрації ХС ЛПНЩ та ХС ЛПДНЩ. Цей показник враховує значення усіх проатерогенних часток ЛП іє значно більш надійним показником ризику розвитку кардіоваскулярної патології та летальності від неї, ніж рівень ХС ЛПНЩ [9].

Приблизно таку ж інформацію надає визначення рівня в крові апоВ, який є відображенням сумарного вмісту ЛПНЩ та ЛПДНЩ. Відомо, що значно посилена продукція апоВ, яка відзначається при інсулінорезистентності гепатоцитів внаслідок усунення пригнічувального впливу інсуліну, а також при активації системного запалення може бути причиною розвитку гіпертриглі- церидемії (ГТЕ). Більше того, посилення синтезу апоВ $\mathrm{i}$, як наслідок, підвищений проатерогенний потенціал крові може відзначатися навіть за відсутності ГТЕ, а підвищення рівня апоВ при низькому значенні апоА-1 поєднується зі значно збільшеним ризиком розвитку коронарного атеросклерозу навіть в умовах нормального або зменшеного вмісту в крові ХС ЛПНЩ [10].

Найбільш закономірним проявом порушеного метаболізму ЛП у осіб з РА порівняно з контролем $є$ значно менша концентрація в крові ХС ЛПВЩ [11], і в ще більшому ступені, як показали наші дослідження, вмісту апоА-1 і зростання відношення апоВ/апоА-1, які знаходилися в чіткій кореляційній залежності з активністю запалення, але не вмісту в крові загального $\mathrm{XC}$ і ХС ЛПНЩ. У низці проведених останнім часом досліджень показано, що аналогічні зміни показників проатерогенного статусу є наслідком запалення високої градації [12].

Ця залежність пов'язана з існуванням двостороннього зв'язку між системним запаленням і обміном ліпідів. Результати низки клінічних досліджень свідчать про те, що цитокіни мають прямий вплив на метаболізм ліпідів у результаті як посиленої продукції ЛПДНЩ у гепатоцитах, так і пригнічення ліпопротеїнової ліпази (ЛПЛ). 3 усіх традиційних ознак проатерогенного профілю ліпідів при запаленні найбільш достовірним є зростання індексу ТГ/ХС ЛПВЩ та відношення апоВ/апоА-1.

У дослідженні, проведеному на 114 пацієнтах із раннім РА, протягом п'яти років спостереження відзначено вірогідне потовщення КІМ сонних артерій і поява в них атеросклеротичних бляшок. Незалежним позитивним предиктором цих змін було збільшення вмісту апоВ, відношення апоВ/апоА-1 та наявність антитіл до фосфорилхоліну, негативним - вміст апоА-1 [3].

Зворотний транспорт ХС від тканин відбувається за рахунок захоплення вільного ХС із поверхні клітин дискоїдальними насцентними ЛПВЩ. ХС може спонтанно дифундувати з поверхні клітин на ЛПВЩ або захоплюватись ними після взаємодії апоА-1 зі специфічним клітинним рецептором ЛПВЩ, що сприяє посиленому переміщенню ХС на клітинну мембрану. Основні білки зворотного транспорту ХC - АТФ-зв'язуючі касетні транспортери A1 та G1, необхідні для ефективної мобілізації XC із макрофагів та запобігання їм трансформації у пінисті клітини. Активатором цих транспортерів $\epsilon$ білок апоА-1 у складі ЛПВЩ [13]. Відзначено, що при активації системного запалення та підвищеній продукції прозапальних цитокінів відбувається заміщення білка апоА-1 у ЛПВЩ на апоА-ІІ. Дані білки проявляють діаметрально протилежні функціональні властивості, і заміщення апоА-1 на апоА-ІІ в ЛПВЩ принципово змінює їх функцію, починаючи від захоплення відтікаючого від клітин вільного ХC, активації лецитинхолестеринацилтрансферази (ЛХАТ) та білка, що транспортує ефіри ХС (БТЕХ) у ЛПВЩ і закінчуючи специфічним захопленням ефірів ХС гепатоцитами. Відомо, що гіперекспресія апоА-1 запобігає розвитку аліментарного атеросклерозу в експерименті, і цей антиатерогенний 
Original research

ефект зменшується при гіперекспресії апоА-II.

У низці клінічних досліджень показано, що в пацієнтів як $з$ анкілозивним спондилітом, так і з РА паралельно з підвищенням плазмового рівня модифікованих ЛПНЩ і ЛПДНЩ зменшується вміст нативних і зростає кількість дисфункціональних ЛПВЩ у результаті заміщення у їх складі протизапального апоА-1 на апоА-II і амілоїдний білок А сироватки (SAA), які мають прозапальну дію [14,15].

Крім того, за результатами досліджень останніх років встановлено, що в умовах системного запалення зростає продукція антитіл до апоА-1 ЛПВЩ, що пригнічує антиатерогенні властивості ЛПВЩ у хворих на РА [16].

В-лімфоцити поділяються на дві основні субпопуляції: клітини В1 та В2. Лімфоцити В1 $є$ антиатерогенними та атеропротекторними, головним чином за рахунок продукції природних антитіл IgM, які зв'язують окиснені ЛПНЩ та ЛПДНЩ. В умовах активації системного запалення під впливом прозапальних цитокінів превалює субпопуляція В2 лімфоцитів у крові у хворих на системні ревматичні захворювання. Однією з проатерогенних функцій цих лімфоцитів $є$ продукція антитіл до апоА-1, що пригнічує здатність ЛПВЩ до захоплення ХС від клітин периферійних тканин та макрофагів [17].

Відмінними рисами системного запалення, яке розвивається при РА, є не тільки висока інтенсивність, а й підвищене значення імунного компонента у розвитку i прогресуванні процесу. У нашому дослідженні вміст ХC і ТГ у ЦІК, що відображає включення в них модифікованих ЛПНЩ (переважно модифікованих МА) і ЛПДНЩ, був значно збільшеним, що вказуває на аутоантигенні властивості цих ЛП і розвиток у результаті аутоімунного запального процесу.

У проведеному дослідженні останніх років визначали концентрацію аутоантитіл (IgG та $\operatorname{IgM}$ ) до модифікованих МА ЛПНЩ і до апоВ-100 у 3509 осіб та їх зв'язок із розвитком несприятливих кардіоваскулярних подій. Вищі титри IgG до модифікованих МА ЛПНЩ незалежно асоціюються з новою кардіоваскулярною подією $[16,18]$. Вважають, що короткочасні зміни метаболізму ліпідів і ЛП при запаленні мають захисне значення, оскільки сприяють інактивації прозапальних цитокінів та активних форм кисню, однак тривалі порушення при хронічному запаленні сприяють розвитку атеросклерозу.

\section{Висновки}

1. У пацієнтів із системними ревматичними захворюваннями навіть у стадії ремісії після проведення антиревматичної терапії зберігається високий рівень системного запалення у поєднанні з вираженим проатерогенним статусом, отже дана категорія пацієнтів повинна розглядатися як особи з високим кардіоваскулярним ризиком, незалежно від стадії захворювання та його вираженості.

2. При визначенні проатерогенних порушень обміну ліпідів і ліпопротеїнів крові у пацієнтів із системними ревматичними захворюваннями потрібно орієнтуватись не на традиційні фактори ризику, які можуть залишатися в межах нормальних значень, а на вміст білків апоА-1,
апоВ, їх співвідношення, на визначення модифікованих ліпопротеїнів крові та вираженості аутоімунної реакції.

\section{Перспективи подальших досліджень}

Подальші дослідження дозволять вивчити патогенетичні механізми розвитку проатерогенних порушень обміну ліпідів і ЛП крові у пацієнтів із системними ревматичними захворюваннями.

\section{Список літератури}

1. Mach F, Baigent C, Catapano AL, Koskinas KC, Casula M, Badimon L, et al. 2019 ESC/EAS Guidelines for management of dyslipidaemias: lipid modifi-cation to reduce cardiovascular risk. Europ Heart J. 2020;41(1):111-88.

2. 2019 Guidelines on Dyslipidaemias (Management of) ESC Clinical Practice Guidelines. Available from: https://www.escardio.org/ Guidelines/Clinical-Practice-Guidelines/Dyslipidaemias-Managementof.

3. Khot UN, Khot MB, Bajzer CT, Sapp SK, Ohman EM, Brener $\mathrm{SJ}$, et al. Prevalence of conventional risk factors in patients with coronary heart disease. JAMA. 2003;290(7):898-904. DOI: 10.1001/ jama.290.7.898

4. Greenland P, Knoll MD, Stamler J, Neaton JD, Dyer AR, Garside DB, et al. Major risk factors as antecedents of fatal and nonfatal coronary heart disease events. JAMA. 2003;290(7):891-97.

5. Navar AM. The Evolving Story of Triglycerides and Coronary Heart Disease Risk. JAMA. 2019;321(14):347-49. DOI: 10.1001/ jama.2018.20044.

6. Tsimikas S, Brilakis ES, Miller ER, McConnell JP, Lennon RJ, Kornman KS, et al. Oxidized Phospholipids, Lp(a) Lipoprotein, and Coronary Artery Disease. N Engl J Med. 2005;353(1):46-57. DOI: 10.1056/NEJMoa043175.

7. Charles-Schoeman C. Cardiovascular disease and rheumatoid arthritis: an up-date. Curr Rheumatol Rep. 2012;14(5):455-62.

8. Otocka-Kmiecik A, Mikhailidis DP, Nicholls SJ, Davidson M, Rysz J, Banach M. Dysfunctional HDL: a novel important diagnostic and therapeutic target in cardiovascular disease? Prog Lipid Res. 2012;51(4):314-24. DOI: 10.1016/j.plipres.2012.03.003.

9. Giannattasio C, Zoppo A, Gentile G, Failla M, Capra A, Maggi FM, et al. Acute effect of high-fat meal on endothelial function in moderately dyslipidemic subjects. Arterioscler Thromb Vasc Biol. 2005;25(2):406-10. DOI: 10.1161/01.ATV.0000152231.93590.17.

10. Kaneva AM, Potolitsyna NN, Bojko ER, Odland JØ. The Apolipoprotein B/Apolipoprotein A-I Ratio as a Potential Marker of Plasma Atherogenicity. Dis Markers. 2015;2015:591454. DOI: $10.1155 / 2015 / 591454$.

11. Ferguson LD, Siebert S, McInnes IB, Sattar N. Cardiometabolic comorbidities in RA and PsA: lessons learned and future directions. Nat Rev Rheumatol. 2019;15(8):461-74. DOI: 10.1038/s41584-019-0256-0.

12. Mahmoudi M, Aslani S, Fadaei R, Jamshidi AR. New Insights to the Mechanisms Underlying Atherosclerosis in Rheumatoid Arthritis. Int J Rheum Dis. 2017;20(3):287-97. DOI: 10.1111/1756-185X.12999.

13. Demina EP, Miroshnikova VV, Shvartsman AL. Role of the $\mathrm{ABC}$ transporters $\mathrm{A} 1$ and $\mathrm{G} 1$, key reverse cholesterol transport proteins, in atherosclerosis. Mol Biol. 2016;50(2):223-30. DOI: 10.7868/ S002689841602004X.

14. Majka DS, Chang RW. Is preclinical autoimmunity benign?: The case of cardiovascular disease. Rheum Dis Clin North Am. 2014;40(4):659-68. DOI: 10.1016/j.rdc.2014.07.006.

15. Meier LA, Binstadt BA. The Contribution of Autoantibodies to Inflammatory Cardiovascular Pathology. Front Immunol. 2018;27(90):911.

16. Prasad A, Clopton P, Ayers C, Khera A, Lemos JA, Witztum JL, et al. Relationship of Autoantibodies to MDA-LDL and ApoBImmune Complexes to Sex, Ethnicity, Subclinical Atherosclerosis, and Cardiovascular Events. Arterioscler Thromb Vasc Biol. 2017;37(6):1213-21.

17. Satta N, Vuilleumier N. Auto-antibodies as possible markers 
Оригінальні дослідження

and mediators of ischemic, dilated, and rhythmic cardiopathies. Curr Drug Targets. 2015;16(4):342-60. DOI: 10.2174/138945011566614 1125122416

18. Tsiantoulas D, Sage AP, Mallat Z, Binder CJ. Targeting B cells

\section{Відомості про авторів}

Гарміш Олена Олексіївна - канд. мед. наук, ст. наук. співр., докторант відділу некоронарних хвороб серця та ревматології ДУ «Національний науковий центр «Інститут кардіології ім. акад. М.Д. Стражеска» НАМН України.

03680, м. Київ, вул. Народного ополчення, 5, garmish.elena@gmail.com, +380679600253.

\section{Сведения об авторах}

Гармиш Елена Алексеевна - канд. мед. наук, ст. научн. сотрудник, докторант отдела некоронарных болезней сердца и ревматологии ГУ «ННЦ «Институт кардиологии им. акад.Н.Д.Стражеско» НАМН Украины.

03680, г. Киев, ул. Народного ополчения, 5 garmish.elena@gmail.com, +380679600253.

\section{Information about the author}

Garmish Olena Oleksiivna - PhD, Doctoral student at the Department of Non-Coronary Heart Diseases and Rheumatology GA «National Scientific Center «M.D. Strazhesko Institute of Cardiology» of NAMS of Ukraine», Kyiv

03680, Kyiv , Narodnogo opolchenia str.,5 garmish.elena@gmail.com, +380679600253.

Надійшла до редакиії 4.09.2020 Рецензент - проф. Тащук В.к. (C) O.O. Гарміш, 2020 